
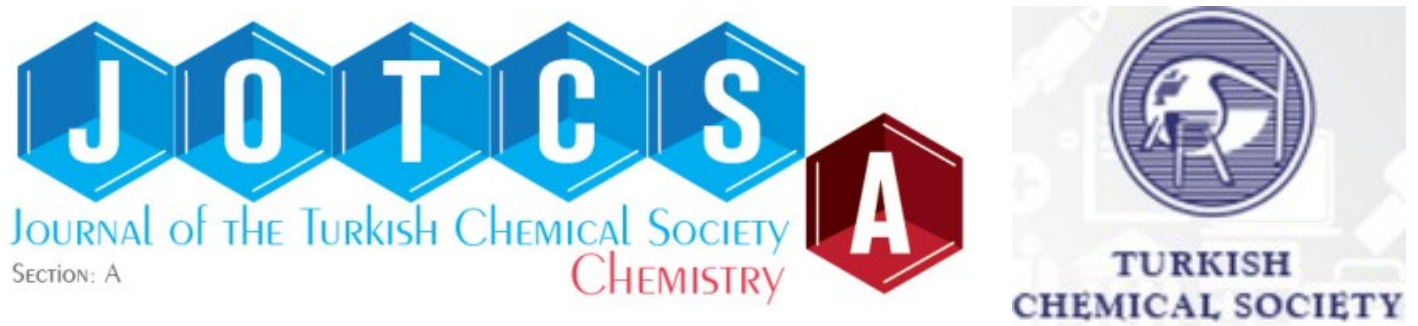

\title{
Investigation of Triamcinolone-Bovine Serum Albumin (BSA) Interaction by Spectroscopic Methods
}

\author{
Sabriye Aydinoglu
}

Çukurova University, Faculty of Pharmacy, Department of Analytical Chemistry, 01330, Adana, Turkey

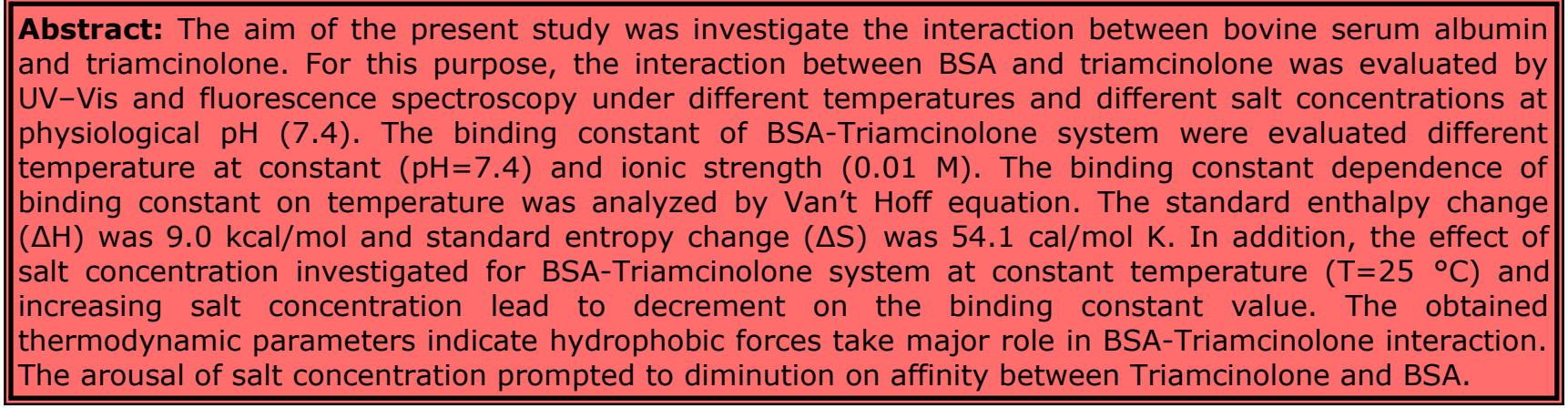

Keywords: Bovine Serum Albumin, Triamcinolone, Drug-protein interaction, thermodynamic, spectroscopy.

Submitted: August 18, 2020. Accepted: October 19, 2020.

Cite this: Aydinoglu S. Investigation of Triamcinolone-Bovine Serum Albumin (BSA) Interaction by Spectroscopic Methods. JOTCSA. 2020;7(3):903-10.

DOI: https://doi.org/10.18596/jotcsa.782263.

*Corresponding author. E-mail: sabriyeaydinoglu@cu.edu.tr.

\section{INTRODUCTION}

Endogeneous ligands and drugs are mostly bound to plasma proteins in the blood. Because of unbound drug freely penetrates to target organs and elimination organs drug-plasma protein interaction determines pharmacokinetics and pharmacodynamics properties of drugs. The drug binding to plasma proteins could cause to alteration on drug half-life time and drug blood concentration (1-3).

Albumin is the most abundant protein in plasma and it is bound reversibly various drugs including anticoagulants, antidiabetics, antineoplastic, and steroids (4-6). The importance of interaction between ligand and albumin or other plasma protein is well recognized (7). The interaction between plasma protein and drugs has significant value in order to understand behavior of drugs in biological systems $(8,9)$. Bovine Serum albumin (BSA) has similarities with Human Serum Albumin (HSA) from the point of structure, properties and functionalities. BSA is widely used to investigate drug-protein interaction because of its similarity with HAS (9-13). Experimental studies with serum albumin is represented a model for in vitro drug plasma protein interaction.

Triamcinolone is a synthetic corticosteroid drug used in the treatment of various inflammatory conditions such as dermatitis, allergic rhinitis, allergic asthma, rheumatoid arthritis and acute exacerbations of multiple sclerosis (14). The aim of present study is estimate the type of interaction between BSA and triamcinolone by thermodynamic approach. The thermodynamic parameters as like, standard enthalpy change $\left(\Delta \mathrm{H}^{\circ}\right)$ and standard entropy change $\left(\Delta \mathrm{S}^{\circ}\right)$, could offer an important evidence about interaction type which force binding between protein and drug molecule (15). For instance, in the case of the hydrophobic interaction both of 
mentioned parameters result positive value (16). On the other hand, if $\Delta \mathrm{H}$ and $\Delta \mathrm{S}$ are negative, it means that the interaction occurs by Van der Waals interactions and hydrogen binding (14). In the case of negative $\Delta \mathrm{H}$ with positive $\Delta \mathrm{S}$ is demonstrate interaction cause by electrostatic interaction (8).

\section{MATERIAL AND METHODS}

All the chemicals were analytical grade and were employed without further purification. Triamcinolone and Bovine Serum Albumin (BSA, 298), and hydrochloric acid $(\mathrm{HCl})$ were purchased from SigmaAldrich (Germany). Ethanol HPLC grade, Sodium hydroxide $(\mathrm{NaOH})$, Sodium Chloride $(\mathrm{NaCl})$, sodium dihydrogen phosphate $\left(\mathrm{NaH}_{2} \mathrm{PO}_{4}\right)$, and disodium hydrogen phosphate $\left(\mathrm{Na}_{2} \mathrm{HPO}_{4}\right)$ were purchased from Merck (Germany). The water used as a reaction medium and to prepare the solutions was ultrapure water was purchased from Tekkim (Turkey). Triamcinolone stock solution $\left(4.5 \times 10^{-3}\right.$ $\mathrm{mol} / \mathrm{L})$ was prepared by directly dissolution of weighed amount of drug in $100 \%$ ethanol. BSA stock solution $\left(1.0 \times 10^{-4} \mathrm{~mol} / \mathrm{L}\right)$ was prepared by dissolving known amount of lyophilized powder in ultrapure water, than stock solution was standardized spectrophotometrically, using $\varepsilon=45000$ $\mathrm{L} / \mathrm{mol} . \mathrm{cm}$ at $278 \mathrm{~nm}$. [27]. A Oheaus Starter 5000 $\mathrm{pH}$ meter equipped with a combined glass electrode was used to perform $\mathrm{pH}$ measurements.

The absorbance spectra of triamcinolone with BSA were recorded by Agilent Cary 100 double beam spectrophotometer equipped with quartz cells $(1 \mathrm{~cm}$ path length) with jacketed cell holders, with temperature control within $\pm 0.1^{\circ} \mathrm{C}$. In order to evaluate the equilibrium constants of TriamcinoloneBSA interaction reaction spectrophotometric titrations were performed as follows: increasing volumes of BSA solution were added with a Hamilton microsyringe (Mitutoyo) to the dye solution directly in the spectrophotometric cell. During spectrophotometric titration, the salt concentration was kept at constant value and after each addition of BSA standard solution the spectra of the solution was recorded. The titrations were repeated for different temparatures and salt concentrations.

On the other hand, spectrofluorometric measurements were done by Cary Eclipse Fluorescence Spectrophotometer at room temperature. In order to perform fluorescent measurements, a serial of drug-protein solutions were prepared with a constant protein concentration and different drug concentrations at constant $\mathrm{pH}$ and salt concentration. Then, the spectrum of each solution were recorded.

\section{RESULTS AND DISCUSSION}

\section{UV-Vis absorbance measurements}

The absorbance spectrum of triamcinolone was taken between $200-400 \mathrm{~nm}$ with gradually increased drug amount and the spectrum is given Figure 1 . A. Lambert-Beer plot of triamcinolone at $242 \mathrm{~nm}$ is demonstrated Figure 1.B.
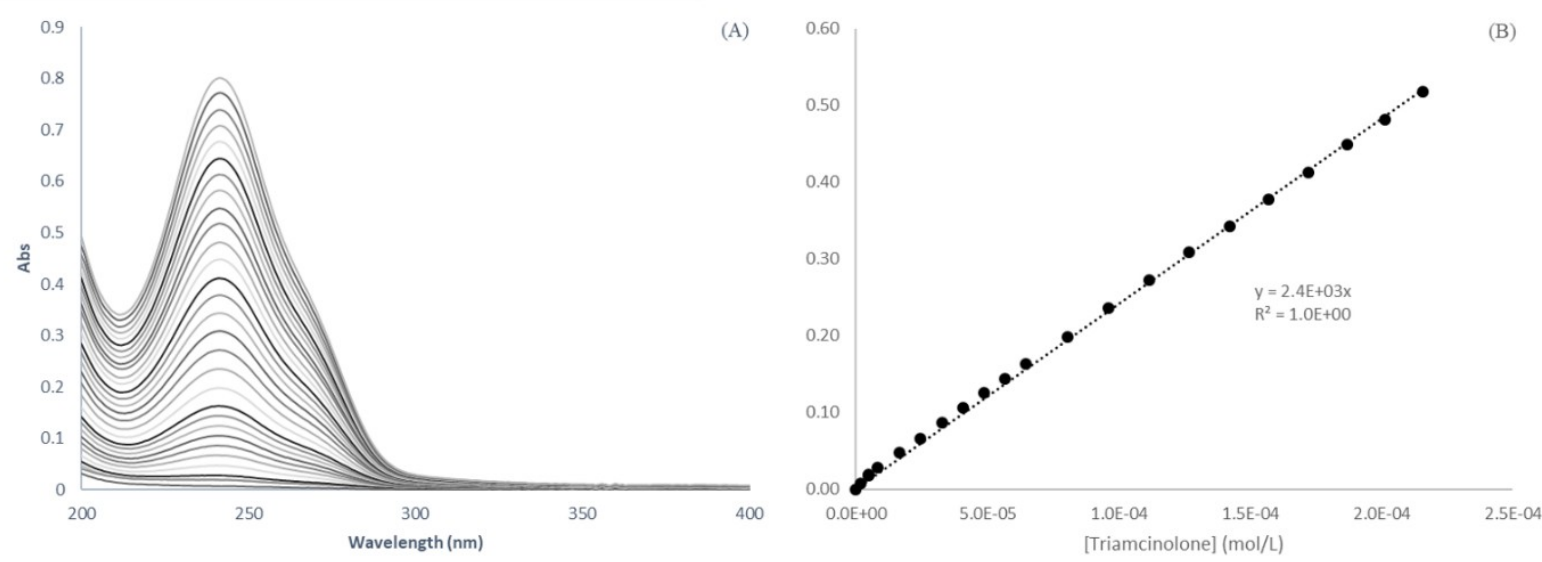

Figure 1. (A) The absorbance spectrum of triamcinolone; (B) The absorbance dependence on drug concentration at $242 \mathrm{~nm}$; [Triamcinolone] $=0-2.2 \times 10^{-4} \mathrm{~mol} / \mathrm{L}, \mathrm{pH}=7.4(\mathrm{PBS}),[\mathrm{NaCl}]=0 \mathrm{~mol} / \mathrm{L}, \mathrm{I}=$ $0.01 \mathrm{~mol} / \mathrm{L}, \mathrm{T}=25^{\circ} \mathrm{C}$.

In order to evaluate binding constant of Triamcinolone-BSA complex formation reaction, spectrophotometric titrations were performed. The absorbance spectrum was recorded with protein addition into drug solution and absorbance spectrum is given in Figure 2. 


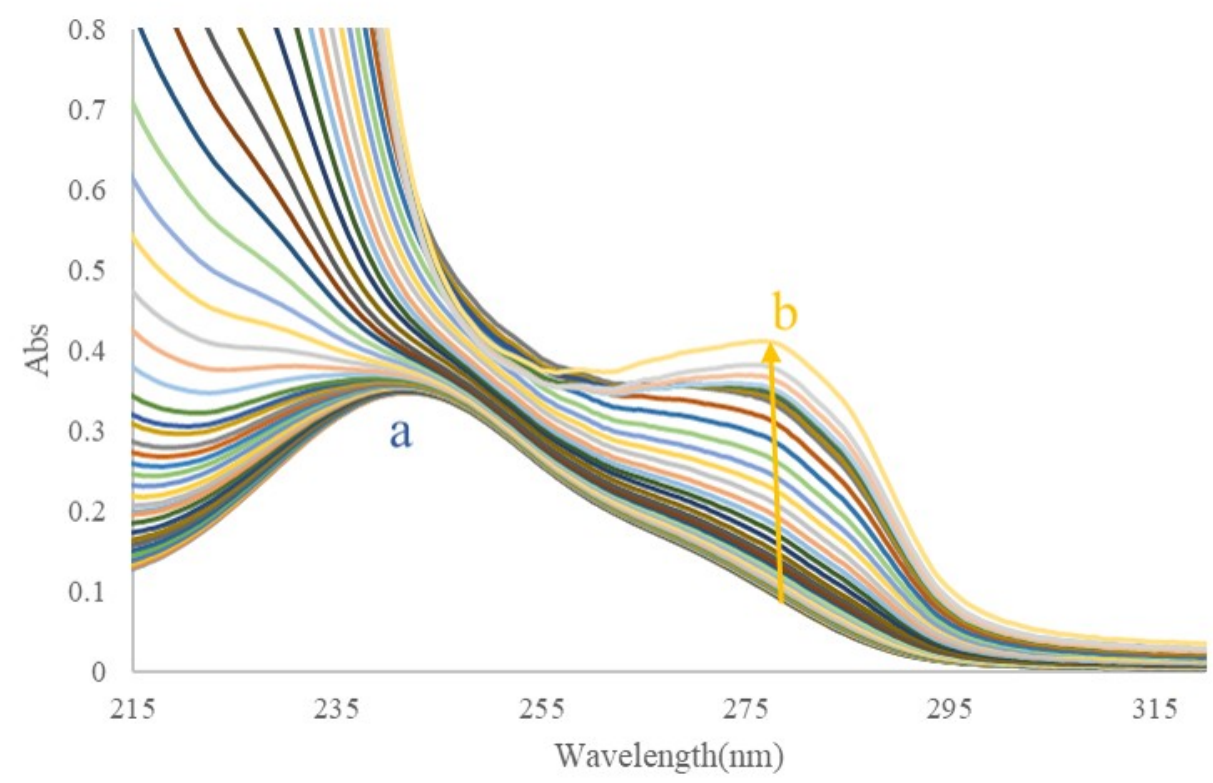

Figure 2. Normalized UV-Vis Spectrum of Triamcinolone-BSA Titration; [triamcinolone] $=2.2 \times 10^{-5} \mathrm{a}$ ) $[B S A]=0 \mathrm{~mol} / \mathrm{L}, \mathrm{b})[\mathrm{BSA}]=4.8 \times 10^{-5} \mathrm{~mol} / \mathrm{L}, \mathrm{pH}=7.4$ (phosphate buffer), $[\mathrm{NaCl}]=0.75 \mathrm{~mol} / \mathrm{L}, \mathrm{T}=25^{\circ} \mathrm{C}$. After titration, the binding constant of studied system was determinated by Equation 1. (17)

$$
\frac{C_{D}}{\Delta A}=\frac{\frac{1}{K \Delta \varepsilon} \times 1}{C_{P}}+\frac{1}{\Delta \varepsilon}
$$

In Eq. $1 C_{D}$ and $C_{P}$ are respectively, analytical concentration of drug and protein while $\Delta \mathrm{A}$ is the difference between after each protein addition measured Absorbance value to initial absorbance value of drug absence of protein, $A_{0}, \Delta A=A-A_{0}$. The binding isotherm of spectrophotometric titration is given Figure 3.A. and analyses of binding isotherm according equation 1 is given Figure 3.B.
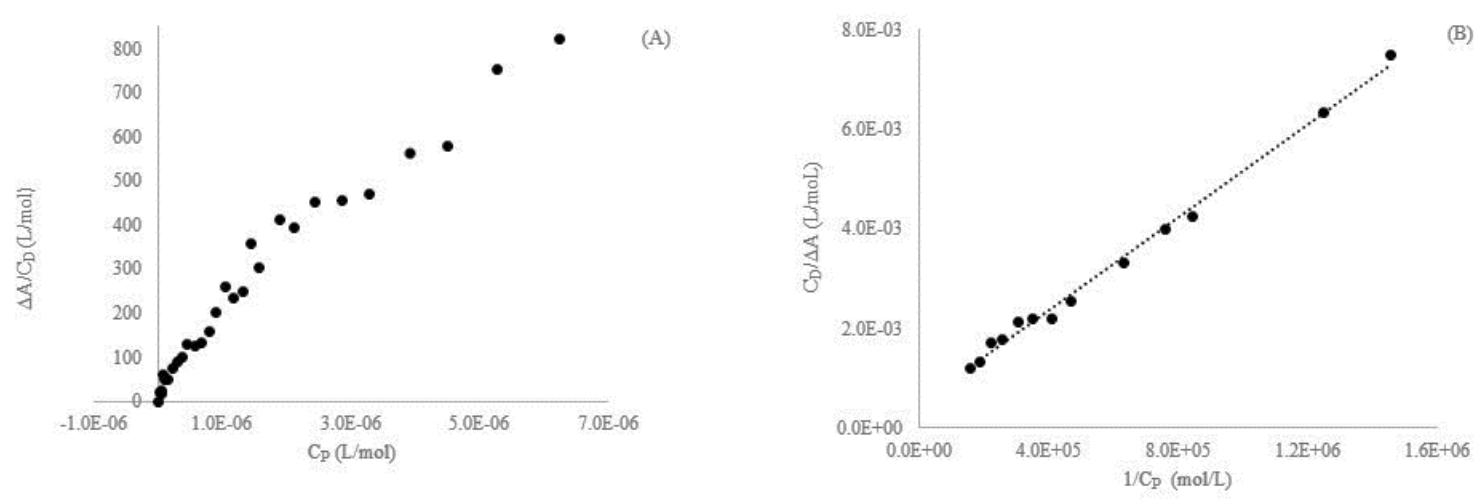

Figure 3. (A) The Binding isotherm for a spectrophotometric titration of Triamcinolone-BSA System; (B) Relevant Data Analysis according Eq. 1 ; [triamcinolone] $=2.2 \times 10^{-5}[\mathrm{BSA}]=0-4.8 \times 10^{-5} \mathrm{~mol} / \mathrm{L}, \mathrm{pH}=7.4$ (phosphate buffer), $[\mathrm{NaCl}]=0.5 \mathrm{~mol} / \mathrm{L}, \mathrm{T}=25^{\circ} \mathrm{C}, \lambda=250 \mathrm{~nm}$.

In order to evaluate thermodynamic parameters as Standard Enthalpy change $\left(\Delta \mathrm{H}^{\circ}\right)$ and Standard Entropy change $\left(\Delta S^{\circ}\right)$, for BSA-Triamcinolone interaction, the binding constants were evaluated at four different temperatures by performing spectroscopic titrations. The observed binding constant values analyzed according to Van't Hoff (Equation 2) in order to evaluate thermodynamic parameters as $\Delta \mathrm{H}^{\circ}$ and $\Delta \mathrm{S}^{\circ}(16)$.

$$
\ln K=\frac{-\Delta H^{\circ}}{R T}+\frac{\Delta S}{R}
$$

The Van't Hoff diagram is given in Figure 4. In addition, free energy change is calculated by Equation 3 (5); 


$$
\Delta G^{\circ}=\Delta H^{\circ}-T \Delta S^{\circ}
$$

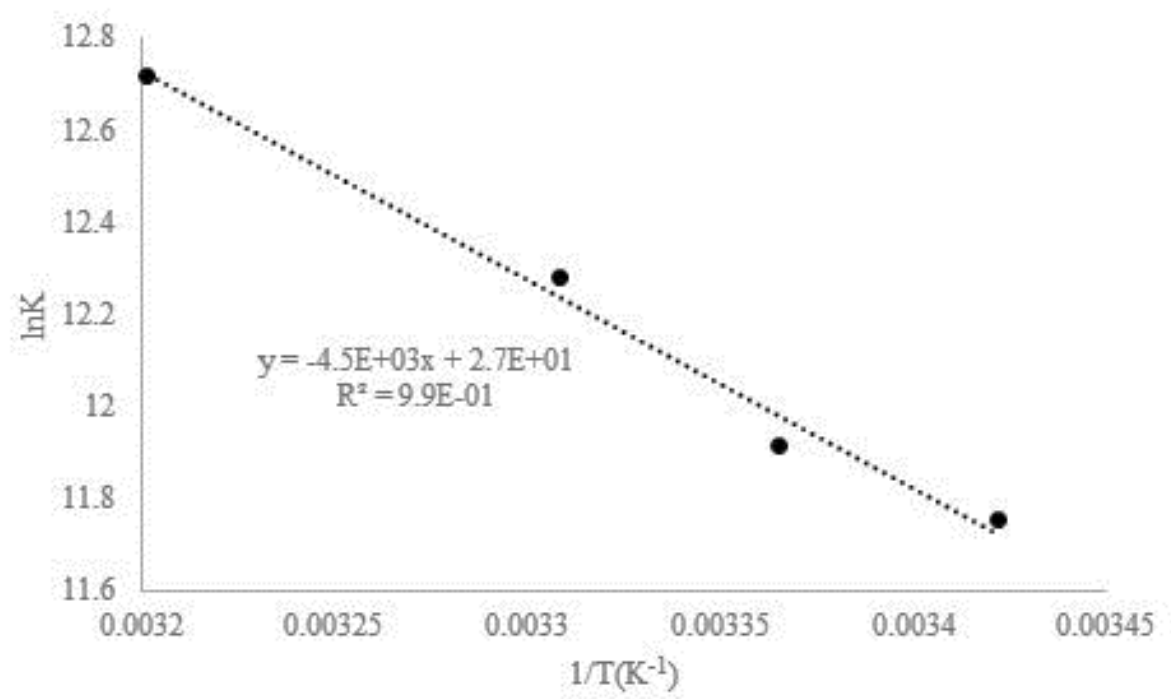

Figure 4. The Van't Hoff plot of BSA-triamcinolone system; $\mathrm{pH}=7.4, \mathrm{I}=0.01 \mathrm{~mol} / \mathrm{L}(\mathrm{PBS}),[\mathrm{NaCl}]=0$ $\mathrm{mol} / \mathrm{L}$.

The obtained binding constant values and thermodynamic parameters are presented in Table 1.

Table 1. Thermodynamic parameters for BSA-triamcinolone system at $\mathrm{pH}=7.4(\mathrm{PBS}), \mathrm{I}=0.01 \mathrm{~L} / \mathrm{mol}$.

\begin{tabular}{ccc}
\hline $\mathbf{T}(\mathbf{K})$ & $\mathbf{K}(\mathbf{L} / \mathbf{m o l})$ & $\mathbf{\Delta G}^{\circ}(\mathbf{k J} / \mathbf{m o l})$ \\
\hline 292.25 & $1.27 \times 10^{5}$ & -28.4846 \\
297.15 & $1.49 \times 10^{5}$ & -29.5938 \\
302.25 & $2.15 \times 10^{5}$ & -30.7483 \\
312.35 & $3.33 \times 10^{5}$ & -33.0347 \\
\hline$\Delta \mathrm{H}^{\circ}(\mathrm{kJ} / \mathrm{mol})$ & & 37.7 \\
$\Delta \mathrm{S}^{\circ}(\mathrm{J} / \mathrm{mol} \mathrm{K})$ & & 226.4 \\
\hline
\end{tabular}

The positive value of $\Delta \mathrm{H}^{\circ}$ and $\Delta \mathrm{S}^{\circ}$ parameters indicate hydrophobic interaction lead to complex formation between BSA-triamcinolone. Moreover, binding constant of BSA-triamcinolone system was determinated at constant temperature different salt concentration. The dependence of binding constant on salt concentration is given Table 2 . 
Table 2. Binding constant of BSA-Triamcinolone system by spectrophotometric titrations; $\mathrm{pH}=7.4(\mathrm{PBS})$, $[\mathrm{NaCl}]=0-0.76 \mathrm{~mol} / \mathrm{L}, \mathrm{T}=25^{\circ} \mathrm{C}$.

\begin{tabular}{ccccc}
\hline [NaCl] & $\mathbf{I}$ & $\log I$ & $\mathbf{K}$ & $\log \mathrm{K}$ \\
\hline 0 & 0.01 & 2.00 & $1.49 \times 10^{5}$ & 5.17 \\
0.1 & 0.11 & 0.96 & $9.99 \times 10^{4}$ & 4.99 \\
0.25 & 0.026 & 0.58 & $7.04 \times 10^{4}$ & 4.85 \\
0.5 & 0.51 & 0.29 & $6.46 \times 10^{4}$ & 4.81 \\
0.75 & 0.076 & 0.12 & $6.03 \times 10^{4}$ & 4.78
\end{tabular}

As seen from Table 2, augmentation of salt concentration caused a reduction in the binding constant of BSA-Triamcinolone system. The reason of this behavior could be explain with in the presence of chloride ions drug affinity to BSA decreases $(4,8)$.

\section{Fluorimetric Study}

Triamcinolone - BSA interaction was also analyzed in a fluorimetric approach. The fluorescence spectrum of BSA solutions in the presence of different concentration of Triamcinolone was recorded at room temperature and the obtained spectrum is given in Figure 5.

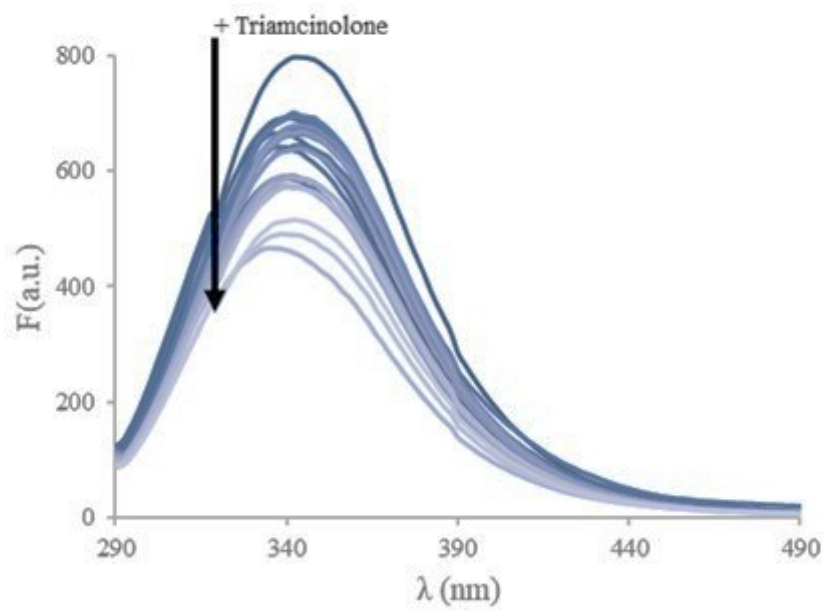

Figure 5. The fluorescence spectra of $B S A$ - triamcinolone system $C(B S A)=5.0 \times 10^{-7} \mathrm{~mol}^{-L^{-1}}$, $\mathrm{C}$ (triamcinolone) $=0 \mathrm{~mol} . \mathrm{L}^{-1}-6 \times 10^{-6} \mathrm{~mol} . \mathrm{L}^{-1}, \mathrm{pH}=7.4$ (Phosphate Buffer), $\mathrm{I}=0.01 \mathrm{~mol} . \mathrm{L}^{-1}, \mathrm{~T}=25^{\circ} \mathrm{C}$, $\lambda_{\mathrm{exc}}=280 \mathrm{~nm}$.

The emission intensity of BSA was diminished noticeably with gradually addition of drug solution which indicates triamcinolone binding to BSA. Also, with addition drug molecule in BSA cause to small blue shift of maximum fluorescence intensity of BSA from $342 \mathrm{~nm}$ to $338 \mathrm{~nm}$. This behavior could explain assuming drug chromophore group movement in more hydrophobic zone.

The binding parameter of BSA-triamcinolone system was analyzed according to Benesi-Hildebrand equation (Equation 4) (18);

$$
\frac{C_{D} \times C_{P}}{\Delta F}+\frac{\Delta F}{(\Delta \varphi)^{2}}=\frac{1}{K \Delta \varphi}+\left(C_{D}+C_{P}\right) \frac{1}{\Delta \varphi}
$$

In Equation 4, $C_{D}$ is total analytical protein concentration and $C_{p}$ is total analytical drug concentration. In order to calculate the binding constant by Eq. 4 iterative procedure was 
performed. The binding isotherm and BenesiHildebrand diagrams are given respectively in Figure
6.A and Figure 6.B.
(A)

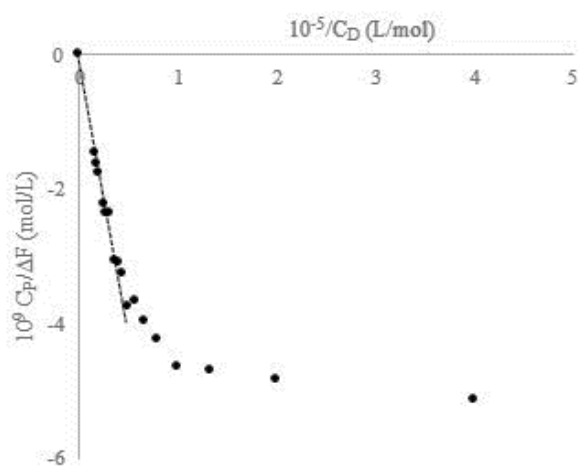

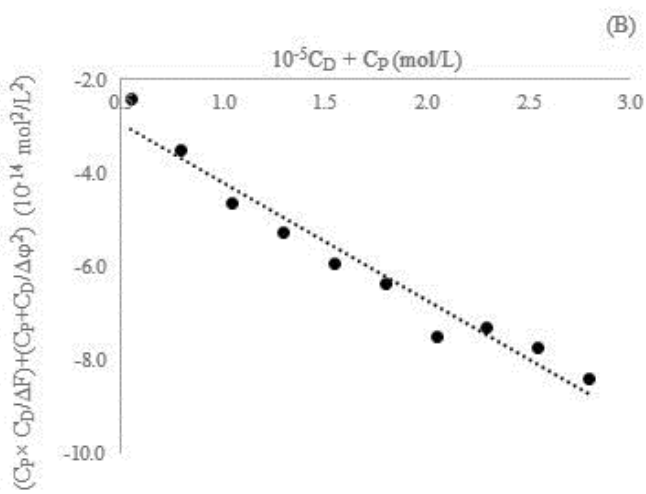

Figure 6. (A) The binding isotherm of spectrofluorometric measurements of BSA-triamcinolone system; (B) Benesi-Hildebrand diagrams for BSA-triamcinolone system; $C(B S A)=5.0 \times 10^{-7} \mathrm{~mol} . \mathrm{L}^{-1}$, $\mathrm{C}($ Triamcinolone $)=0 \mathrm{~mol} . \mathrm{L}^{-1}-6 \times 10^{-5} \mathrm{~mol} . \mathrm{L}^{-1}, \mathrm{pH}=7.4$ (phosphate buffer), $\mathrm{I}=0.01 \mathrm{~mol} . \mathrm{L}^{-1}, \mathrm{~T}=25{ }^{\circ} \mathrm{C}$, $\lambda_{\mathrm{exc}}=280 \mathrm{~nm}$.

The binding constant value was evaluated as $\mathrm{K}=1.47 \times 10^{5} \quad \mathrm{~L} / \mathrm{mol}$ by spectrofluorometric measurement good agreement with $\mathrm{K}=1.49 \times 10^{5} \mathrm{~L} /$ mol obtained by spectrophotometric measurement under same experimental conditions $\left(T=25^{\circ} \mathrm{C}\right.$, $\mathrm{I}=0.01 \mathrm{M}, \mathrm{pH}=7.4$ ).

On the other hand, BSA quenching by drug molecule was evaluated by using Equation 5 (13);

$$
\frac{F_{0}-F}{F}=\frac{1}{f K_{S V}(Q)}+\frac{1}{f}
$$

where, $\mathrm{K}_{\mathrm{SV}}$ is Stern-Volmer constant of BSATriamcinolone system, where $F_{0}$ is intensity of BSA absence of drug while $F$ is intensity of BSA in the presence of drug. $Q$ is drug concentration and $f$ is the fractional maximum fluorescence intensity of protein. The Stern-Volmer plot is given Figure 7.

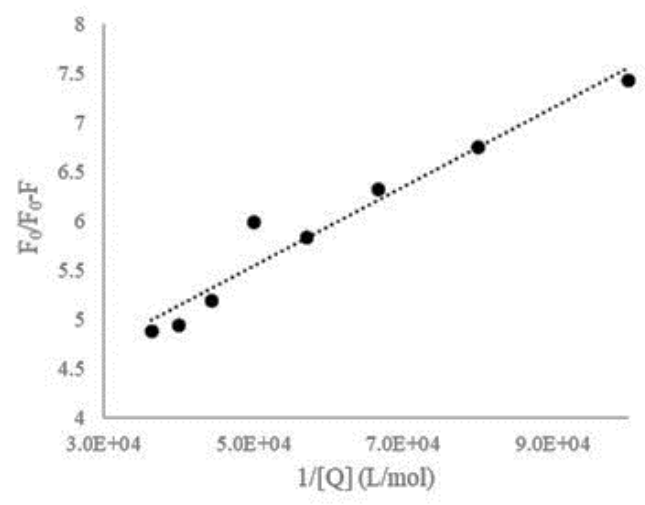

Figure 7. Stern-Volmer Plot for BSA-triamcinolone system obtained by fluorescence measurement. C(BSA) $=5.0 \times 10^{-7} \mathrm{~mol} . \mathrm{L}^{-1}, \mathrm{pH}=7.4$ (phosphate buffer) $, \mathrm{I}=0.01 \mathrm{~mol} . \mathrm{L}^{-1}, \mathrm{~T}=25^{\circ} \mathrm{C}, \lambda_{\text {exc }}=280 \mathrm{~nm}$.

The Stern-Volmer constant being equal to the binding constant causes when BSA-Triamcinolone complex does not fluoresce (16). Therefore, SternVolmer constant determined different from binding constant as $8.8 \times 10^{4} \mathrm{~L} / \mathrm{mol}$. Even if thermodynamic results were pointed hydrophobic interactions as a main force of binding, increase of salt concentration caused negative effect on binding constant. This effect might explain with Triamcinolone displacement with chloride ions $(4,8)$.

\section{CONCLUSION}

In the present study, BSA-Triamcinolone interaction was investigated by spectrophotometric and spectrofluorometric measurement. The binding 
constant of system was determined for both methods in to order of $10^{5}$ which indicate binding affinity of Triamcinolone to BSA is quite high. Moreover, the obtained positive thermodynamic parameters as like $\Delta H^{\circ}$ and $\Delta S^{\circ}$ indicate BSATriamcinolone interaction occurs due to hydrophobic forces. On the other hand, negative free energy change point to spontaneity of studied reaction. The interaction studies were repeated at different salt concentration to understand salt effect on studied system.

\section{REFERENCES}

1. Fasano M, Curry S, Terreno E, Galliano M, Fanali G, Narciiso P, Notari S, Ascenzi P. The extraordinary ligand binding properties of human serum albumin. IUBMB, Life. 2005; 57: 787 - 96. Doi: $10.1080 / 15216540500404093$.

2. Rizzuti B, Bartucci R, Pey AL, Guzzi R. Warfarin increases thermal resistance of albumin through stabilization of the protein lobe that includes its binding site. Archives of Biochemistry and Biophysics. 2019; 676:(108123) 1-8. Doi: 10.1016/j.abb.2019.108123.

3. Pilati D, Kenneth A. Howard Albumin-based drug designs for pharmacokinetic modulation. Expert Opinion on Drug Metabolism \& Toxicology. 2020; Doi: 10.1080/17425255.2020.1801633.

4. Wilting J, Van Der Giesen WF, Janssen LHM. The effect of chloride on the binding of warfarin to albumin as a function of $\mathrm{pH}$. Biochemical Pharmacology.

Doi:10.1016/j.proeng.2010.09.152.

5. Kandagal PB, Ashoka S, Seetharamappa J, Shaikh SMT, Jadegoud Y, Ijare OB. Study of the interaction of an anticancer drug with human and bovine serum albumin spectroscopic approach. Journal of Pharmaceutical and Biomedical Analysis. 2006; 41: 393-9. Doi: 10.1016/j.jpba.2005.11.037.

6. Fender AC, Dobrev D. Bound to bleed: How altered albumin binding may dictate warfarin treatment outcome. IJC Heart \& Vasculature. 2019; 22: 214-5.

7. Al-Harthi S, Lachowicz JI, Nowakowski ME. Towards the functional high-resolution coordination chemistry of blood plasma human serum albumin. Journal of Inorganic Biochemistry. 2019; 198: (110716) 1-15.

8. Seedher N, Bhatia S. Mechanism of interaction of the non-steroidal antiinflammatory drugs meloxicam and nimesulide with serum albumin. Journal of Pharmaceutical and Biomedical Analysis. 2005; 39: 257-69.
9. Sharifi M, Dolatabadi JEN, Fathi F, Rashidi M, Jafari B, Tajalli H, Rashidi MR. Kinetic and thermodynamic study of bovine serum albumin interaction with rifampicin using surface plasmon resonance and molecular docking methods. Journal of Biomedical Optics. 2017; 22: (037002)1-6. Doi: 10.1117/1.JBO.22.3.037002.

10. Raghav D, Mahanty S, Rathinasamy K. Characterizing the interactions of the antipsychotic drug trifluoperazine with bovine serum albumin: Probing the drug-protein and drug-drug interactions using multi-spectroscopic approaches. Spectrochimica Acta Part A: Molecular and Biomolecular Spectroscopy. 2020; 226: (117584) 114. doi: 10.1016/j.saa.2019.117584.

11. Chakraborty B, Basu S. Interaction of BSA with proflavin: A spectroscopic approach. Journal of Luminescence. 2009; 129: 34-9. Doi: 10.1016/j.jlumin.2008.07.012.

12. Jha NS, Kishore N. Thermodynamic studies on the interaction of folic acid with bovine serum albumin. The Journal of Chemical Thermodynamics. 2011; 43: 814-21. Doi: 10.1016/j.jct.2010.12.024.

13. Tian J, Liu J, Hu Z, Chen X. Interaction of wogonin with bovine serum albumin. Bioorganic \& Medicinal Chemistry. 2005; 13: 4124-9. Doi: 10.1016/j.bmc.2005.02.065

14. Goyal RN, Gupta VK, Chatterjee S. A sensitive voltammetric sensor for determination of synthetic corticosteroid triamcinolone abused for doping. Biosensors and Bioelectronics. 2009; 35628. Doi: 10.1016/j.bios.2009.05.016.

15. Chaires JB. Energetics of Drug-DNA. Current Opinion in Structural Biology. 1998; 8:31420.

16. Macii F, Salvadori G, Bonini R, Giannarelli $S$, Mennucci $B$, Biver $T$. Binding of model polycyclic aromatic hydrocarbons andcarbamate-pesticides to DNA, BSA, micelles and liposomes. Spectrochimica Acta Part A: Molecular and Biomolecular Spectroscopy. 2019; 223: (117313)1-9. Doi: 10.1016/j.saa.2019.117313.

17. Aydinoglu $\mathrm{S}$, Biver $\mathrm{T}$, Figuccia $\mathrm{S}$, Fiore $\mathrm{T}$, Montanaro $S$, Pellerito $C$. Studies on DNA interaction of organotin(IV) complexes of mesotetra(4-sulfonatophenyl)porphine that show cellular activity. Journal of Inorganic Biochemistry. 2016; 163: 311-7. Doi: 10.1016/j.jinorgbio.2016.06.030

18. Beccia MR, Biver $T$, Pardini A, Spinelli J, Secco F, Venturini M, Jacopo Spinelli, Fernando Secco, Marcella Venturini, Vázquez Busto N, Cornejo Lopez MP, Martin Herrera VI, Gotor RP. The 
Aydinoglu S. JOTCSA: 2020; 7(3): 903-910.

fluorophore 4',6-diamidino-2-phenylindole (DAPI) Chemistry - An Asian Journal. 2012; 7; 1803-10. induces DNA folding in long double-stranded DNA. Doi: 10.1002/asia.201200177. 